\title{
SEMICONDUCTOR DRIVER OF PYROELECTRIC ACCELERATOR OF CHARGED PARTICLES
}

\author{
O.O. Ivashchuk ${ }^{1}$, A.V. Shchagin ${ }^{1,2}$, A.S. Kubankin ${ }^{1,3}$, V.Yu. Ionidi ${ }^{4}$, A.S. Chepurnov ${ }^{4}$ \\ ${ }^{1}$ Belgorod State National Research University, Belgorod, Russia; \\ ${ }^{2}$ National Science Center “Kharkov Institute of Physics and Technology”, Kharkiv, Ukraine; \\ ${ }^{3}$ Lebedev Physical Institute, Moscow, Russia; \\ ${ }^{4}$ Skobeltsyn Institute of Nuclear Physics, Moscow, Russia \\ E-mail: ooleg.ivashuk@gmail.com
}

The possibility for application of semiconductor element for heating of pyroelectric crystalin a pyroelectric accelerator of charged particles or pyroelectric X-ray generator is at first proposed and demonstrated experimentally. Spectra of X-ray radiation measured at the heating of the pyroelectric crystal $\mathrm{LiNbO}_{3}$ by silicon diode at different pressures of residual gas are presented. Perspectives for application of semiconductor heater in the pyroelectric accelerators and X-ray generators are discussed.

PACS: 29.17.+w; 77.70.+a

\section{INTRODUCTION}

Pyroelectric accelerator of elementary charged particles operates due to variation of the temperature of the pyroelectric crystal $[1,2]$ or ferroelectric ceramics [3] in vacuum. The size of the pyroelectric element usually is about $1 \mathrm{~cm}$. In the most of experiments, it is heated up to temperature about $100 \ldots 200^{\circ} \mathrm{C}$ and cooled to room or lower temperature. Different methods of heating and cooling of a pyroelectric element in vacuum are used. For instance, it is heated by a resistor [4 - 6], evanescent

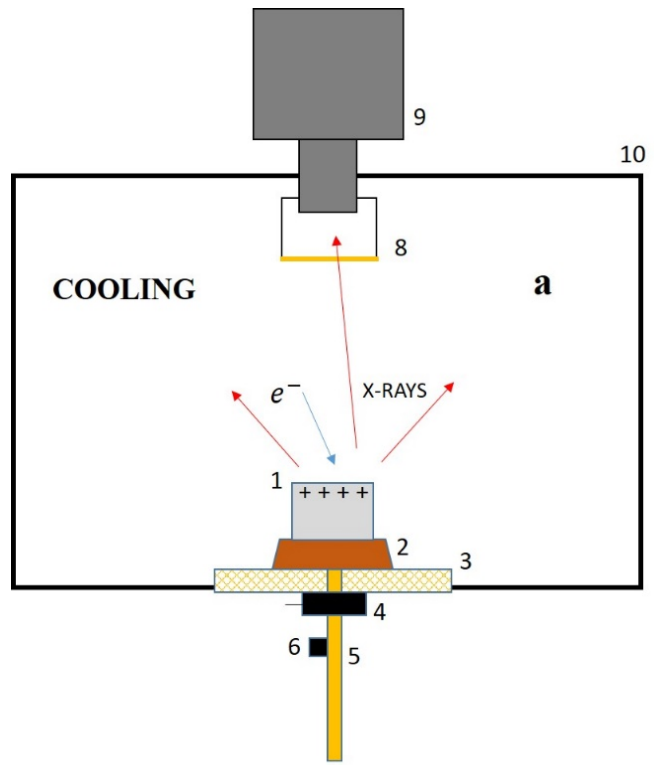

lamp [7], Peltier element [8, 9], inductive heater [10], ultraviolet laser [11]. Passive cooling up to room temperature is possible due to thermal radiation [12]. Active cooling with use of Peltier element [13] or liquid nitrogen $[14,15]$ allows reach negative in ${ }^{\circ} \mathrm{C}$ temperatures. Here we propose heating of pyroelectric elements in vacuum by a semiconductor diode or transistor. Experimental verification of semiconductor driving of the pyroelectric accelerator is presented and its advantages are discussed.

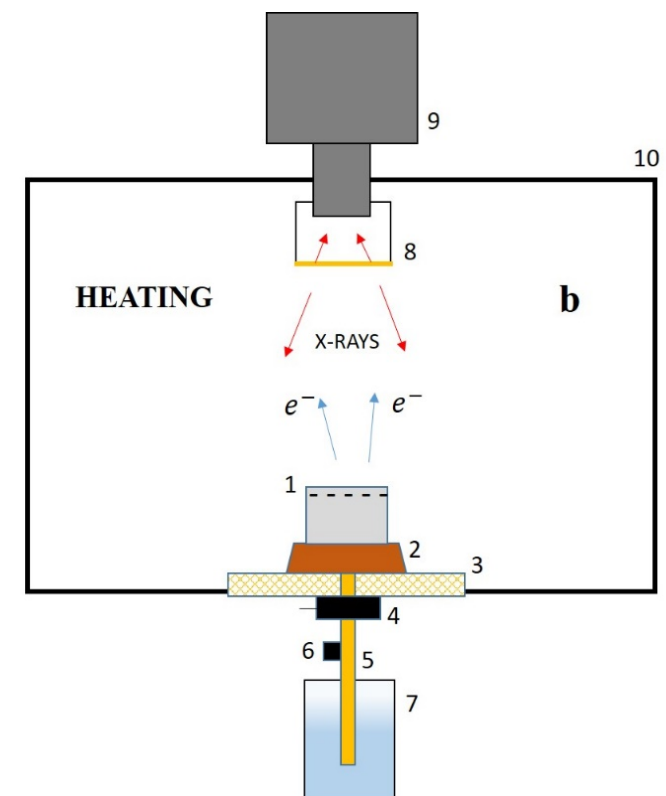

Fig. 1. The experimental layout (during heating (a) and cooling (b) of the pyroelectric crystal in vacuum). 1 - pyroelectric crystal $\mathrm{LiNbO}_{3} ; 2$ - copper substrate; 3 -foil fiber glass flange that provides good electrical conductivity and temperature isolation from walls of vacuum chamber 10; 4 - silicon diode MUR 1560; 5 - coperrod;

6 - thermocouple K type; 7 - liquid nitrogen tank; 8 -copper foil target; 9 -semiconductor X-ray detector

The main elements of pyroelectric accelerator and $\mathrm{X}$-ray generator was cylindric pyroelectric crystal made of $\mathrm{LiNbO}_{3}$ material with of diameter $10 \mathrm{~mm}$ and height $5 \mathrm{~mm}$. The $\mathrm{Z}$ axis of the crystal is aligned along the cylinder axis. The pyroelectric crystal was attached to the copper substrate using conductive epoxy glue inside vacuum chamber. The copper substrate was attached to copper rod, that was located outside vacuum chamber. In our experiments we used the specialized vacuum flange made of double-sided fiberglass for thermal insulation and electric contact between the copper substrate and vacuum chamber. In this experiment the heating semiconductor element was installed outside vacuum chamber. To the copper rod outside of vacuum chamber was attached $\mathrm{Si}$ diode. The Si rectifier 15 Amps diode of type MUR1560 that operate in junction temperature range -65 to $+175^{\circ} \mathrm{C}$ and has low junction-to-case thermal resistance $1.5^{\circ} \mathrm{C} / \mathrm{W}$. Popular TO-220 package of the 
diode with flat heat conductor allows simple connection to a pyroelectric element. For the measurement of temperature change of the pyroelectric crystal during the work of diode we used thermocouple $\mathrm{K}$ type, that was attached to copper rod using non-conductive glue BF-2. For the measurement of yield of X-rays generated during work of the pyroelectric accelerator the semiconductor X-ray detector Amptek CdTe 123 was installed inside vacuum chamber opposite of the free surface of the pyroelectric crystal. The peaking time of spectrometer was $0.2 \mu \mathrm{s}$ in this experiment. Energy calibration of the spectrometer was performed using X-ray lines of ${ }^{237} \mathrm{~Np}$. In front of the entrance berylliumwindow of the detector at a distance of $3 \mathrm{~mm}$ copper foil target with thickness $30 \mu \mathrm{m}$ was installed.

During work of the semiconductor silicon diode at the current $10 \mathrm{~A}$ after $375 \mathrm{~s}$ the temperature of the pyroelectric crystal was changed from +25 to $+90^{\circ} \mathrm{C}$. The negative potential about $60 \mathrm{kV}$ appeared on the free surface of the pyroelectric crystal leading to acceleration of electrons that emitted from the free surface of the pyroelectric crystal towards grounded copper target up to energy $60 \mathrm{keV}$ (Fig. 1,b). We observed X-ray generation due to the electron's deceleration on the target atoms. High voltage potential, that appeared due to pyroelectric effect, didn't increase during heating of the pyroelectric crystal above $90^{\circ} \mathrm{C}$. When the temperature of the pyroelectric crystal achieved $+90^{\circ} \mathrm{C}$ work of the diode was stopped and copper rod was put in the liquid nitrogen tank. So, the pyroelectric crystal cooled during $1130 \mathrm{~s}$. from +90 to $-80^{\circ} \mathrm{C}$ (Fig. 1,a). The positive potential appeared on the free surface of the pyroelectric crystal.

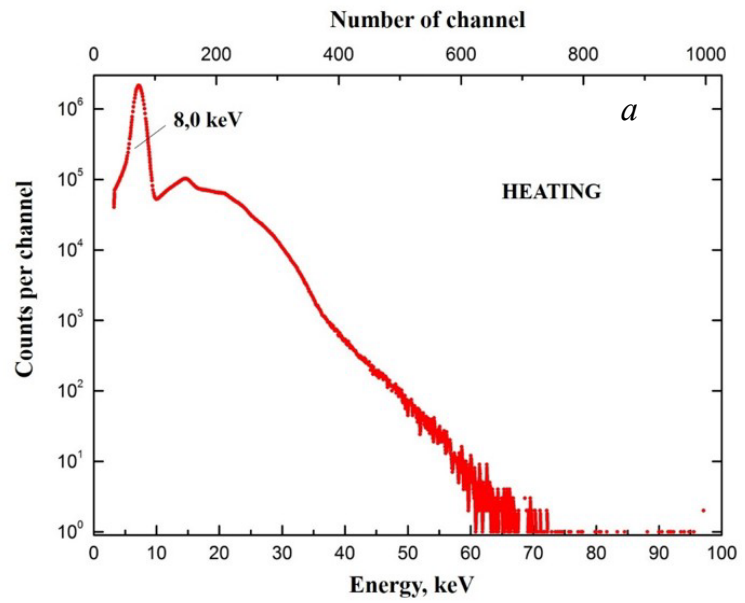

We observed X-ray generation due to the electron's deceleration on the crystal atoms. Then the pyroelectric crystal heated from -80 to $+90^{\circ} \mathrm{C}$. Such cycle heatingcooling was repeated at the different pressures of the residual gas in vacuum chamber.

The spectrum of $\mathrm{X}$-ray radiation at the heating of the pyroelectric crystal from -80 to $+90^{\circ} \mathrm{C}$ in vacuum was measured during $475 \mathrm{~s}$. The spectrum of X-ray radiation measured at the heating of the pyroelectric crystal is presented in Fig. 2,a. The spectral peak with the energy $8.0 \mathrm{keV}$ on bremsstrahlung background corresponds to the peak of the characteristic X-ray $\mathrm{K}_{\alpha}$ cooper atom. The maximum energy of the bremsstrahlung $\mathrm{X}$-ray radiation measured at the heating of the pyroelectric crystal by semiconductor silicon diode in vacuum is $75 \mathrm{keV}$ and number of counts registered in whole spectrum at the heating is 55717670 .

The spectrum of X-ray radiation at the cooling of the pyroelectric crystal from +90 to $-80^{\circ} \mathrm{C}$ in was measured during $1130 \mathrm{~s}$ is presented in Fig. 2,b. Spectrum contains peaks of characteristic X-ray radiation on the background of bremsstrahlung. The spectral peak with the energy $8.0 \mathrm{keV}$ corresponds to the peak of the characteristic X-ray $\mathrm{K}_{\alpha}$ cooper atom. The spectral peak with the energy $16.6 \mathrm{keV}$ corresponds to the peak of the characteristic $\mathrm{X}$-ray $\mathrm{K}_{\alpha}$ niobium atom composing the pyroelectric crystal. The maximum energy of the bremsstrahlung X-ray radiation measured at the cooling of the pyroelectric crystal in vacuum is $40 \mathrm{keV}$ and number of counts registered at the cooling is 1277266.

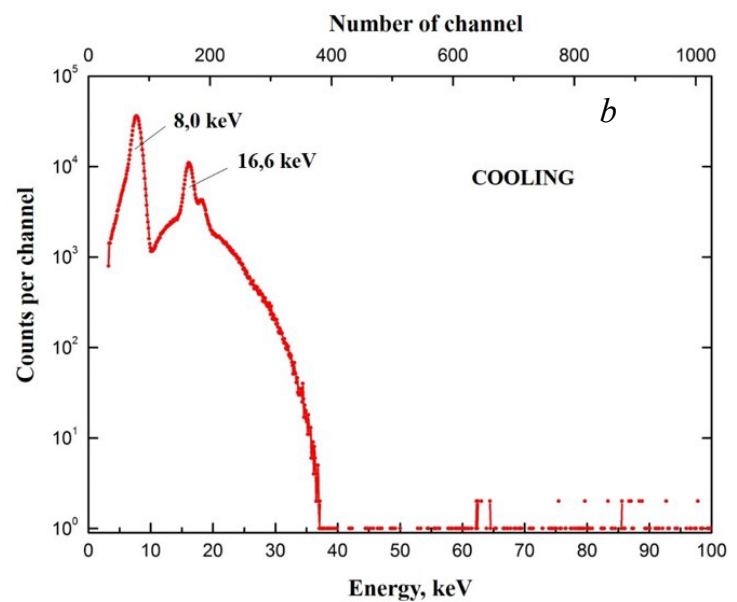

Fig. 2. Spectra of X-ray radiation measured at the heating (a) and at the cooling of the pyroelectric crystal in vacuum (b)

Both spectra of X-ray radiation were measured at the pressure of the residual gas $0.8 \mathrm{mT}$ Torr in vacuum chamber. The experimental setup was equipped by the regulated vacuum valve that was installed between the pumping system, including turbomolecular for-vacuum pumps, and vacuum chamber. This provided the possibility to change the pressure of the residual gas in vacuum chamber. The pressure of the residual gas in vacuum chamber was controlled by the vacuum gauge, designed to measure high vacuum.

The experimental dependence of total number of counts and maximum energy of the X-rays, generated at the heating of the pyroelectric crystal as a function of the pressure of the residual gas is presented in Fig. 3,a. The maximum yield of $\mathrm{X}$-ray radiation is at the pressure of the residual gas $0.1 \mathrm{mT}$ Torr.

The experimental dependence of total number of counts and maximum energy of the X-rays, generated at the cooling of the pyroelectric crystal as a function of the pressure of the residual gas is presented in Fig. 3,b. The maximum energy of $\mathrm{X}$-ray radiation and accelerated electrons is at the pressure of the residual gas 1 mTorr. 

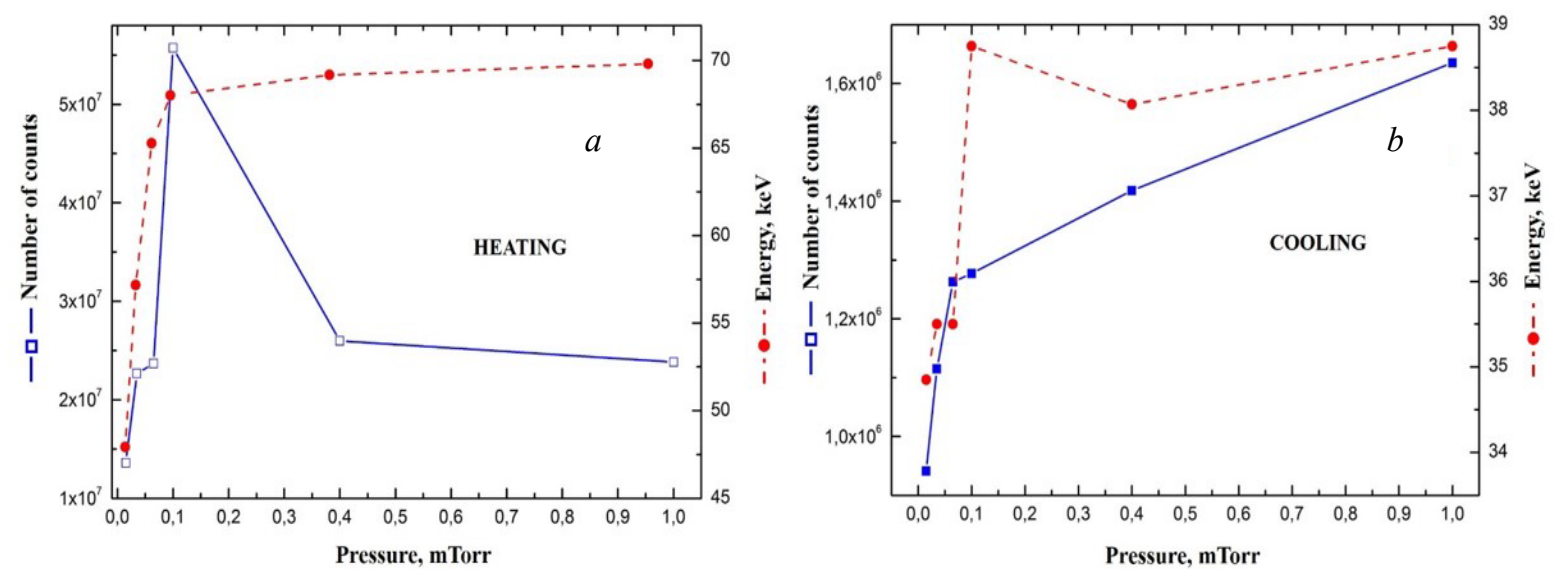

Fig. 3. The total number of counts and maximum energy in the X-ray spectra, measured at the heating (a) and at the cooling (b) of the pyroelectric crystal as functions of the pressure of the residual gas in vacuum chamber. Thus, results of presented experiments clearly demonstrate applicability of semiconductor heater, installed outside of the vacuum chamber, for control of a pyroelectric accelerator

\section{DISCUSSION}

Semiconductor Si diode driver of pyroelectric accelerator seems is very convenient for applications because it has low outgas in vacuum, the heating rate is easy regulated by the value of the forward current at almost permanent voltage about $1 \mathrm{~V}$, low thermal resistance, wide operating temperature range up to $+175^{\circ} \mathrm{C}$, and its commercial availability. The source of the heat is thin semiconductor junction of submillimeter thickness. Lowest operating temperature up to about $-65^{\circ} \mathrm{C}$ allows application of an outer cooling, e.g. by liquid nitrogen. One can use a transistor instead of diode and regulate power by the value of the base current. Other semiconductor materials with another temperature range can be used in a specific condition.

Besides, one can install an array of pyroelectric elements on the array of semiconductor diodes or transistors mounted in Si chip and obtain chip source of the array of the beams of accelerated charged particles.

\section{ACKNOWLEDGEMENTS}

The work was financially supported by a Program of the Ministry of Education and Science of the Russian Federation for higher education establishments, (project № 3.1631.2017/4.6).

\section{REFERENCES}

1. J.D. Brownridge. Pyroelectric X-ray generator // Nature. 1992, v. 358, p. 287.

2. B. Rosenblum, P. Braunlich, and J.P. Carrico. Electron and positive ion acceleration with pyroelectric crystals // Appl. Phys. Lett. 1974, v. 25, p. 17.

3. A.V. Shchagin, V.S. Miroshnik, V.I. Volkov, and A.N. Oleinik. Ferroelectric ceramics in a pyroelectric accelerator // Appl. Phys. Lett. 2015, v. 107, p. 233505.

4. J.D. Brownridge and S.M. Shafroth. Self-focused electron beams produced by pyroelectric crystals on heating or cooling in dilute gases // Appl. Phys. Lett. 2001, v. 79, p. 3364.

5. J.D. Brownridge and S.M. Shafroth. X-ray fluoresced high- $Z$ (up to $Z=82$ ) $\mathrm{K} X$-rays produced by $\mathrm{LiNbO}_{3}$ and $\mathrm{LiTaO}_{3}$ pyroelectric crystal electron accelerators // Appl. Phys. Lett. 2004, v. 85, p. 1298.
6. J.A. Geutherand Y. Danon. Electron and positive ion acceleration with pyroelectric crystals // Journal of Applied Physics. 2005, v. 97, p. 074109.

7. S.M. Shafroth, W. Kruger, J.D. Brownridge. Time dependence of X-ray yield for two crystal X-ray generators // Nuclear Instruments and Methods in Physics Research A. 1999, v. 422, p. 1-4.

8. A.S. Kubankin, A.S. Chepurnov, O.O. Ivashchuk, V.Yu. Ionidi, I.A. Kishin, A.A. Klenin, A.N. Oleinik, and A.V. Shchagin. Optimal speed of temperature change of a crystal in a pyroelectric X-ray radiation source // AIP Advances. 2018, v. 8, p. 035207.

9. C. Dias, M. Simon, R Quard, and D.K. Das-Gupta. Measurement of the pyroelectric coefficient in composites using a temperature-modulated excitation // J. Phys. D: Appl. Phys. 1993, v. 26, p. 106.

10. M. Klopfer, V. Satchouk, Anh Cao, T. Wolowiec, Y. Alivov, S. Molloi. Demonstration of a noncontact X-ray source // Nuclear Instruments and Methods in Physics Research A. 2015, v.779, p. 124-131.

11. T. Kisa K. Murakami, S. Abo, F. Wakaya, and M. Takai. Electron emission from $\mathrm{LiNbO}_{3}$ crystal excited by ultraviolet laser // Journal of Vacuum Science and Technology B. 2010, v. 28, p. C2B27.

12. C.M. McCartney, T. Richardson, M.A. Pavier, F. Davis, C.J.M. Stirling. The temporal and thermal stability of pyroelectric calix [8] arene Langmuir-Blodgett films Thin Solid Films. 1998, 327-329, 431-434.

13. J.D. Brownridge and S. Raboy. Investigation of pyroelectric generation of X-rays // Journal of Applied Physics. 1999, v. 86, p. 640.

14. J.D. Brownridge, A.J. Telesca, C.R. Stannard, and T.P. O'Brien. Cryogenic pyroelectricity: Demonstrating a newly discovered phenomenon in the classroom // Phys. Tech. 1990, v. 27(7), p. 482.

15. V.I. Nagaychenko, V.M. Sanin, A.M. Yegorov, and A.V. Shchagin. Spectra of pyroelectric X-ray generator // Problems of Atomic Science and Technology. Series “Nuclear Physics Investigations”. 2004, № 2, p. 214.

Article received 29.10.2019 


\section{ПОЛУПРОВОДНИКОВЫЙ ДРАЙВЕР ПИРОЭЛЕКТРИЧЕСКОГО УСКОРИТЕЛЯ ЗАРЯЖЕННЫХ ЧАСТИЦ}

\section{О.О. Иващук, А.В. Щагин, А.С. Кубанкин, В.Ю. Иониди, А.С. Чепурнов}

Впервые предложена и продемонстрирована экспериментально возможность применения полупроводникового элемента для нагрева пироэлектрического кристалла в пироэлектрическом ускорителе заряженных частиц или пироэлектрическом рентгеновском генераторе. Представлены спектры рентгеновского излучения, измеренные при нагреве пироэлектрического кристалла $\mathrm{LiNbO}_{3}$ кремниевым диодом при различном давлении остаточного газа. Также обсуждаются перспективы применения полупроводникового нагревателя в пироэлектрическом ускорителе рентгеновских генераторов.

\section{НАПІВПРОВІДНИКОВИЙ ДРАЙВЕР ПІРОЕЛЕКТРИЧНОГО ПРИСКОРЮВАЧА ЗАРЯДЖЕНИХ ЧАСТИНОК \\ О.О. Іващук, А.В. Щагін, О.С. Кубанкін, В.Ю. Іоніді, О.С. Чепурнов}

Вперше запропоновано і продемонстрована експериментально можливість застосування напівпровідникового елемента для нагріву піроелектричного кристала в піроелектричному прискорювачі заряджених частинок або піроелектричному рентгенівському генераторі. Представлено спектри рентгенівського випромінювання, виміряні при нагріванні піроелектричного кристала $\mathrm{LiNbO}_{3}$ кремнієвим діодом при різноманітному тиску залишкового газу. Також обговорюються перспективи застосування напівпровідникового нагрівача в піроелектричному прискорювачі рентгенівських генераторів. 